\title{
Evaluation of Perinatal Outcomes in Intrahepatic Cholestasis of Pregnancy
}

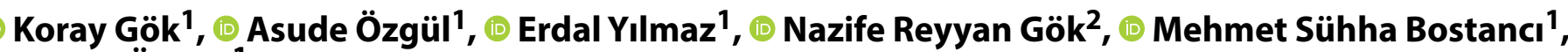 \\ Selcuk Özden ${ }^{1}$
}

${ }^{1}$ Department of Obstetrics and Gynecology, Sakarya University Faculty of Medicine, Sakarya, Turkey

${ }^{2}$ Department of Pediatrics, Division of Neonatology, Istanbul Health Sciences University Umraniye Training and Research Hospital, Istanbul, Turkey

\begin{abstract}
Introduction: This study aimed to retrospectively evaluate the perinatal outcomes of the cases followed up in our clinic for Intrahepatic cholestasis of pregnancy (ICP).

Methods: In this study, the medical records of 71 patients who applied to Sakarya University Training and Research Hospital, Gynecology and Obstetrics Clinic between April 2015 and March 2021 and were diagnosed with ICP were analyzed retrospectively.

Results: The mean age of the patients was $28.9 \pm 4.8$ years. At the time of diagnosis, the mean week of gestation was $31.9 \pm 2.4$ weeks, and the mean week of gestation at birth was $36.7 \pm 1.5$ weeks. It was determined that 20 (28.2\%) of the patients had preterm birth before 37 weeks of gestation. The gestational week at the time of diagnosis was found to be statistically signifi-

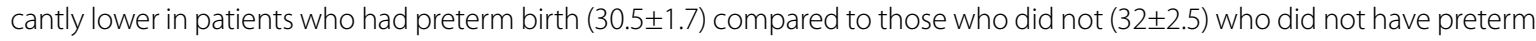
birth (p:0.025). When the correlation analysis was performed, a statistically significant negative correlation was found between the gestational week at the time of diagnosis and preterm birth $(p=0.024, r=-0.268)$.

Discussion and Conclusion: Although ICP is a benign condition for the mother, it can cause significant complications in the fetus. Therefore, early diagnosis and active management are essential in reducing adverse complications related to ICP. Keywords: Intrahepatic cholestasis; perinatal outcomes; pregnancy.
\end{abstract}

I ntrahepatic cholestasis of pregnancy (ICP) is the most common pregnancy-specific liver disease characterized by itching, increased bile acids, and liver transaminases, usually in the late second and third trimesters of pregnancy [1-3]. The incidence is estimated to vary between $0.3 \%$ and $15 \%$ in various populations ${ }^{[4]}$. Although the pathophysiology of ICP remains unclear, many factors related to genetic predisposition, reproductive hormones, and environmental factors are thought to play a critical role in the pathogenesis of ICP [4-6].
ICP is associated with adverse perinatal outcomes such as spontaneous preterm birth, meconium-stained amniotic fluid, fetal distress, respiratory distress syndrome, need for neonatal intensive care, and stillbirth ${ }^{[7-9]}$. Although factors such as placental microstructure disorders and fetal arrhythmia are blamed, the pathogenesis of these complications, including stillbirth, remains unclear ${ }^{[10-12]}$. In the literature, studies are showing that adverse perinatal outcomes increase, especially in cases where the total bile acid (TBA) level is $\geq 40 \mu \mathrm{mol} / \mathrm{I}^{[7,13]}$.

Correspondence (Illetişim): Koray Gök, M.D. Sakarya Universitesi Tip Fakultesi Kadin Hastaliklari ve Dogum Anabilim Dali, Sakarya, Turkey Phone (Telefon): +90 5327149738 E-mail (E-posta): drkorayctf@hotmail.com 
This study aimed to retrospectively evaluate the perinatal outcomes of the cases followed up in our clinic for ICP.

\section{Materials and Methods}

In this study, the medical records of 71 patients who applied to Sakarya University Training and Research Hospital, Gynecology and Obstetrics Clinic between April 2015 and March 2021 and were diagnosed with ICP were analyzed retrospectively. This study was approved by the university ethics committee (E-71522473-050.01.04-21471-228). Pregnant women with persistent itching and increased TBAs $(\geq 10 \mu \mathrm{mol} / \mathrm{l})$ in maternal blood without any liver and skin pathology were considered as ICP. Cases with a TBA level $\geq 10 \mu \mathrm{mol} / \mathrm{l}-40 \mu \mathrm{mol} / \mathrm{I}$ were evaluated as mild ICP, and those with $\geq 40 \mu \mathrm{mol} / \mathrm{I}$ were considered severe ICP [14,15]. Patients with chronic liver diseases, skin diseases, allergic disorders, symptomatic cholelithiasis, or ongoing viral infections affecting the liver (Hepatitis $A, B$, and $C$ virus, Cytomegalovirus, Herpes Simplex virus, and Ebstein-Barr virus) were excluded from the study.

Ursodeoxycholic acid (10-15 mg/kg/day) was administered in all patients diagnosed with ICP. Before starting the treatment, venous blood samples were taken from the patients at the time of admission, and laboratory parameters including serum aspartate aminotransferase, alanine aminotransferase, gamma-glutamyl transpeptidase, total bilirubin, and alkaline phosphatase levels were evaluated.

Fetal well-being was assessed with a modified biophysical profile that included weekly non-stress testing and amniotic fluid index assessment. Preterm birth was defined as birth before 37 weeks of gestation. If there was no other complication, the patients were delivered after 37 weeks of gestation.

Delivery type and birth weight were obtained from medical records in all cases. In addition, adverse perinatal outcomes such as preterm birth, $1^{\text {st }}$ and $5^{\text {th }}$ min Apgar scores, meconium-stained amniotic fluid, cesarean section due to fetal distress, and need for neonatal intensive care were obtained from the records.

Statistical analyzes were performed using the SPSS 24.0 package program (SPSS Inc. and Lead Tech. Inc. Chicago. USA). In numerical data, the distribution of patients was examined with the Kolmogrov-Smirnov test. Mann-Whitney $U$ test was used when there was no normal distribution. Chi-square and Fisher's exact tests were used for categorical variables. Results were considered statistically significant when the results were at $95 \%$ confidence interval and $p<0.05$. Descriptive statistics (mean, standard deviation, median, minimum, maximum) for numerical variables and frequency distributions (number, percentage) for categorical variables were given. The correlation was evaluated using the Spearman correlation coefficient.

\section{Results}

The demographic and clinical characteristics of the patients are shown in Table 1. The mean age of the patients was $28.9 \pm 4.8$ years. The mean week of gestation at the time of diagnosis was $31.9 \pm 2.4$ weeks, and the mean week of gestation at birth was $36.7 \pm 1.5$ weeks. Three of the cases (4.2\%) were multiple pregnancies (twin pregnancies). It was determined that $20(28.2 \%)$ of the patients had preterm birth before 37 weeks of gestation. While 27 cases (38\%) were born by normal vaginal delivery, 44 of them (62\%) were born by cesarean section. The incidence of gestational diabetes and preeclampsia in the study population was $4.2 \%$ $(n=3)$ and $2.8 \%(n=2)$, respectively. In one (1) case, rheumatoid arthritis was observed as an additional disease. Mean 1st and 5th min Apgar scores were $8.5 \pm 0.8$ and 9.7 \pm 1.3 , respectively. No death was observed in the antenatal and neonatal periods in any of the cases.

The laboratory parameters of the patients are shown in Table 2. 59 patients (83.1\%) with TBA $\geq 10 \mu \mathrm{mol} / \mathrm{l}-40 \mu \mathrm{mol} /$

Table 1. Demographic and clinical characteristics of the patients

\begin{tabular}{lcc}
\hline & Mean \pm SD & Min.-Max. \\
\hline Maternal age (years) & $28.9 \pm 4.8$ & $19-41$ \\
Gravida (number) & $2.4 \pm 1.2$ & $1-5$ \\
Parity (number) & $1 \pm 0.9$ & $0-4$ \\
Gestational week at the time & $31.9 \pm 2.4$ & $28-38.1$ \\
of diagnosis & & \\
Gestational age at birth (weeks) & $36.7 \pm 1.5$ & $30.4-38.7$ \\
Birth weight (g) & $2963 \pm 485.8$ & $1715-3940$ \\
$1^{\text {st }}$ min Apgar score & $8.5 \pm 0.8$ & $5-9$ \\
$5^{\text {th }}$ min Apgar score & $9.6 \pm 0.7$ & $7-10$ \\
\hline
\end{tabular}

SD: Std. Deviation, Min: Minimum, Max: Maximum.

Table 2. Laboratory values of the patients

\begin{tabular}{lcc}
\hline & Mean \pm SD & Min.-Max. \\
\hline aspartate aminotransferase $(\mathrm{U} / \mathrm{l})$ & $96.4 \pm 75.2$ & $14-362$ \\
alanine aminotransferase $(\mathrm{U} / \mathrm{l})$ & $139.5 \pm 117.8$ & $7-506$ \\
gamma-glutamyl transpeptidase $(\mathrm{U} / \mathrm{l})$ & $35.1 \pm 65$ & $6-514$ \\
Alkalene phosphatase $(\mathrm{U} / \mathrm{l})$ & $214.2 \pm 108.7$ & $102-850$ \\
Total bilirubin $(\mu \mathrm{mol} / \mathrm{l})$ & $0.8 \pm 0.5$ & $0.1-3.2$ \\
TBA $(\mu \mathrm{mol} / \mathrm{l})$ & $29.7 \pm 28.1$ & $10.1-147.5$ \\
\hline
\end{tabular}

SD: Std. Deviation; Min: Minimum; Max: Maximum. 
I,TBA $\geq 40 \mu \mathrm{mol} /-100 \mu \mathrm{mol} / 8$ patients (11.3\%) and 4 patients (5.6\%) if TBA $\geq 100 \mu \mathrm{mol} / /$ were followed.

The gestational week at the time of diagnosis was found to be statistically significantly lower in patients who had preterm delivery $(30.5 \pm 1.7)$ compared to those who did not have preterm delivery $(32 \pm 2.5)(p=0.025)$.

When the correlation analysis was performed, a statistically significant negative correlation was found between the gestational week at the time of diagnosis and preterm birth $(p=0.024, r=-0.268)$.

The distribution of adverse perinatal outcomes and clinical characteristics between mild and severe ICP groups is shown in Table 3.59 patients (83.1\%) were diagnosed as mild ICP and 12 patients (16.9\%) as severe ICP. Although meconium-stained amniotic fluid was observed in only 2 cases, it was observed that these cases were in the mild ICP group. Although adverse perinatal outcomes such as preterm birth and neonatal intensive care unit admission were more common in the severe ICP group than in the mild ICP group, no statistically significant difference was found between the groups.

\section{Discussion}

According to the results of our study, the rate of preterm birth was found to be high (28.2\%) in cases of ICP. In addition, there is a statistically significant negative correlation between the gestational week at the time of diagnosis and preterm birth. Although negative perinatal outcomes such as preterm birth and admission to the neonatal intensive

Table 3. Distribution of adverse perinatal outcomes and clinical characteristics between mild and severe ICP groups

\begin{tabular}{|c|c|c|c|}
\hline Parameters & Mild (n=59) & Severe $(n=12)$ & $\mathbf{p}$ \\
\hline Fetal distress & $10(16.9 \%)$ & $1(8.3 \%)$ & 0.676 \\
\hline Preterm birth & $15(25.4 \%)$ & $5(41.7 \%)$ & 0.299 \\
\hline $\begin{array}{l}\text { Neonatal intensive care } \\
\text { unit admission }\end{array}$ & $5(8.5 \%)$ & $3(25 \%)$ & 0.127 \\
\hline Type of delivery & & & 0.515 \\
\hline Vaginal delivery & 21 & 6 & \\
\hline Cesarean section & 38 & 6 & \\
\hline $\begin{array}{l}\text { Gestational week at the } \\
\text { time of diagnosis }\end{array}$ & $31.67 \pm 2.46$ & $31.29 \pm 2.31$ & 0.902 \\
\hline $\begin{array}{l}\text { Gestational age at } \\
\text { birth (weeks) }\end{array}$ & $36.97 \pm 1.28$ & $36.09 \pm 2.25$ & 0.392 \\
\hline Birth weight $(g)($ Mean $\pm S D)$ & $3028.6 \pm 489.5$ & $2640.4 \pm 319.3$ & 0.006 \\
\hline $1^{\text {st }} \min$ Apgar score & $8.6 \pm 0.8$ & $8.4 \pm 1$ & 0.540 \\
\hline $5^{\text {th }}$ min Apgar score & $9.6 \pm 0.7$ & $9.5 \pm 0.8$ & 0.456 \\
\hline
\end{tabular}

SD: Std. Deviation; n: number. care unit were observed more and more as the severity of the disease increased, this situation was not found to be statistically significant.

The mechanism of preterm birth, which is one of the important complications of ICP, still remains unclear ${ }^{[16-18]}$. A study stated that a cholic acid-mediated increase in oxytocin receptor expression might lead to preterm birth by increasing oxytocin sensitivity in the myometrium ${ }^{[19]}$. The frequency of preterm birth in ICP has been investigated in various studies ${ }^{[20-22]}$. Zhang et al., ${ }^{[21]}$ reported a preterm birth rate of $12.5 \%$ in the mild ICP group and $47.5 \%$ in the severe ICP group. In a study investigating the role of postprandial bile acids in the prediction of ICP, $18.5 \%$ and $53.3 \%$ preterm birth were reported in mild and severe ICP, respectively ${ }^{[21]}$. In another study, the authors evaluated the rate of preterm birth based on TBA levels. In the group with TBA $<20 \mu \mathrm{mol} / \mathrm{l}$, TBA $20-39 \mu \mathrm{mol} / \mathrm{l}$, and TBA $>40 \mu \mathrm{mol} / \mathrm{l}$, they reported the preterm birth rate as $38.8 \%, 25.5 \%$ and $46.4 \%$, respectively ${ }^{[22]}$. In our study, the preterm birth rate was $28.2 \%$ in the whole patient group, $25.4 \%$ in mild ICP, and $41.7 \%$ in severe ICP, and these results were similar to the literature.

Although ICP is usually diagnosed in the late second trimester or at the beginning of the $3^{\text {rd }}$ trimester, there are also cases reported in the literature in the $8^{\text {th }}$ gestational week $^{[23]}$ and $20^{\text {th }}$ gestational week ${ }^{[23]}$. In one study, patients were divided into two groups according to the time of diagnosis: $\leq 28$ weeks of gestation (early-onset ICP) and $>28$ weeks of gestation (late-onset ICP). Researchers stated that adverse perinatal outcomes, including preterm birth, were more common in the early-onset group. ${ }^{[24]}$ Oruc et al., ${ }^{[21]}$ and Madazlı et al.,, ${ }^{[22]}$ reported the gestational week at the time of diagnosis as $32.25 \pm 2.39,32.6 \pm 3.4$, respectively, and stated that adverse perinatal outcomes were more common in cases with early diagnosis. We found the gestational week at the time of diagnosis to be $31.9 \pm 2.4$, similar to these studies. However, in our study, a significant relationship was found between the gestational week at the time of diagnosis and only preterm birth, one of the adverse perinatal outcomes. In another study, although the gestational week at the time of diagnosis was found to be 34.1 \pm 3.3 , higher than our study, it was found to be significantly associated with the rate of preterm birth, similar to ours ${ }^{[25]}$. In light of this information, knowing the gestational week at which ICP was diagnosed may help manage the disease and determine the negative consequences that may occur.

Gestational diabetes and preeclampsia are significant ob- 
stetric complications, and their frequency in pregnancy is $4-11 \%$ and $2-8 \%$, respectively.[27,28] Wikström Shemer et al., ${ }^{[4]}$ emphasized that ICP has a strong relationship with gestational diabetes and preeclampsia and should be considered in diagnosing women with ICP. Researchers stated in their study that the risk of gestational diabetes and pre-eclampsia in patients complicated with ICP increased compared to the group not complicated with ICP, and they stated the rate of these diseases as $2.7 \%$ and $6.7 \%$, respectively ${ }^{[4]}$. In another study conducted later, the incidence of gestational diabetes and pre-eclampsia was reported as $14.6 \%$ and $2.2 \%$, respectively ${ }^{[22]}$. In our study, gestational diabetes and pre-eclampsia incidences were $4.2 \%$ and $1.4 \%$, respectively, and were not different from the normal population. The reason for this difference between studies may be due to different patient groups and numbers.

Stillbirth is another important adverse event that is known to increase in ICP compared to normal pregnancies. In two extensive studies in the literature, it has been shown that the risk of stillbirth increases in cases where the TBA level is $>100 \mu \mathrm{mol} / \mathrm{I}^{[7,28]}$. In our study, TBA was $\geq 100 \mu \mathrm{mol} / /$ in only four patients, and stillbirth was not found in all patient groups. This difference may be due to the small number of patients in our study.

There are several limitations of this study. First, it is a retrospective study. Secondly, due to the low number of patients in the severe ICP group and the absence of a control group, adequate comparisons between the healthy group and the patient group could not be made. However, these problems can be overcome with multicenter prospective studies among larger patient groups.

\section{Conclusion}

Although ICP is a benign condition for the mother, it can cause significant complications in the fetus. In this study, we found that the rate of preterm birth increased significantly in ICP, which was related to the gestational week at the time of diagnosis. Therefore, early diagnosis and active management are essential in reducing adverse complications related to ICP.

Ethics Committee Approval: This study was approved by the university ethics committee (E-71522473-050.01.04-21471-228).

Peer-review: Externally peer-reviewed.

Authorship Contributions: Concept: K.G., S.Ö., M.S.B.; Design: K.G., S.Ö., M.S.B., A.Ö.; Data Collection or Processing: K.G., A.Ö., E.Y.; Analysis or Interpretation: K.G., N.R.G., M.S.B.; Literature Search: K.G., N.R.G., M.S.B., E.Y.; Writing: K.G., S.Ö.
Conflict of Interest: None declared.

Financial Disclosure: The authors declared that this study received no financial support.

\section{References}

1. Dixon PH, Williamson C. The pathophysiology of intrahepatic cholestasis of pregnancy. Clin Res Hepatol Gastroenterol 2016;40:141-53. [CrossRef]

2. Shao Y, Chen J, Zheng J, Liu CR. Effect of histone deacetylase HDAC3 on cytokines IL-18, IL-12 and TNF- $a$ in patients with intrahepatic cholestasis of pregnancy. Cell Physiol Biochem 2017;42:1294-302. [CrossRef]

3. Clinical updates in women's health care summary: Liver disease: Reproductive considerations. Obstet Gynecol 2017;129:236. [CrossRef]

4. Wikström Shemer E, Marschall HU, Ludvigsson JF, Stephansson O. Intrahepatic cholestasis of pregnancy and associated adverse pregnancy and fetal outcomes: A 12-year population-based cohort study. BJOG 2013;120:717-23. [CrossRef]

5. Geenes V, Williamson C. Intrahepatic cholestasis of pregnancy. World J Gastroenterol 2009;15:2049-66. [CrossRef]

6. Joshi D, James A, Quaglia A, Westbrook RH, Heneghan MA. Liver disease in pregnancy. Lancet 2010;375:594-605. [CrossRef]

7. Ovadia C, Seed PT, Sklavounos A, Geenes V, Di Ilio C, Chambers $J$, et al. Association of adverse perinatal outcomes of intrahepatic cholestasis of pregnancy with biochemical markers: Results of aggregate and individual patient data meta-analyses. Lancet 2019;393:899-909. [CrossRef]

8. Labbe C, Delesalle C, Creveuil C, Dreyfus M. Cholestases intrahepatiques gravidiques (CIG) précoces et tardives : étude des complications materno-fœtales [Early and later intrahepatic cholestasis of pregnancy (ICP): Study of adverse pregnancy outcomes]. Gynecol Obstet Fertil Senol 2018;46:388-94. [Article in French] [CrossRef]

9. Yang J, Chen C, Liu M, Zhang S. Women successfully treated for severe intrahepatic cholestasis of pregnancy do not have increased risks for adverse perinatal outcomes. Medicine (Baltimore) 2019;98:e16214. [CrossRef]

10. Geenes VL, Lim YH, Bowman N, Tailor H, Dixon PH, Chambers J, et al. A placental phenotype for intrahepatic cholestasis of pregnancy. Placenta 2011;32:1026-32. [CrossRef]

11. Ibrahim E, Diakonov I, Arunthavarajah D, Swift T, Goodwin $M$, Mcllvride $S$, et al. Bile acids and their respective conjugates elicit different responses in neonatal cardiomyocytes: Role of Gi protein, muscarinic receptors and TGR5. Sci Rep 2018;8:7110. [CrossRef]

12. Güven D, Altunkaynak BZ, Altun G, Alkan I, Kocak I. Histomorphometric changes in the placenta and umbilical cord during complications of pregnancy. Biotech Histochem 2018;93:198210. [CrossRef]

13. Cui D, Zhong Y, Zhang L, Du H. Bile acid levels and risk of adverse perinatal outcomes in intrahepatic cholestasis of pregnancy: $A$ meta-analysis. J Obstet Gynaecol Res 2017;43:1411-20. [CrossRef] 14 . South australia maternal \& neonatal community of practice. 
Obstetric cholestasis. Available at: https://www.sahealth. sa.gov.au/wps/wcm/connect/f91fbf004ee530b2a5ebadd150ce4f37/obstetric+cholestasis_27042016.pdf?MOD=AJPERES. Accessed Apr, 2016.

15. Bicocca MJ, Sperling JD, Chauhan SP. Intrahepatic cholestasis of pregnancy: Review of six national and regional guidelines. Eur J Obstet Gynecol Reprod Biol 2018;231:180-7. [CrossRef]

16. Glantz A, Marschall HU, Mattsson LA. Intrahepatic cholestasis of pregnancy: Relationships between bile acid levels and fetal complication rates. Hepatology 2004;40:467-74. [CrossRef]

17. Kondrackiene J, Beuers U, Zalinkevicius R, Tauschel HD, Gintautas V, Kupcinskas L. Predictors of premature delivery in patients with intrahepatic cholestasis of pregnancy. World J Gastroenterol 2007;13:6226-30. [CrossRef]

18. Pata O, Vardarelı E, Ozcan A, Serteser M, Unsal I, Saruç M, et al. Intrahepatic cholestasis of pregnancy: Correlation of preterm delivery with bile acids. Turk J Gastroenterol 2011;22:602-5.

19. Germain AM, Kato S, Carvajal JA, Valenzuela GJ, Valdes GL, Glasinovic JC. Bile acids increase response and expression of human myometrial oxytocin receptor. Am J Obstet Gynecol 2003;189:577-82. [CrossRef]

20. Zhang Y, Hu L, Cui Y, Qi Z, Huang X, Cai L, et al. Roles of PPARY/ NF-KB signaling pathway in the pathogenesis of intrahepatic cholestasis of pregnancy. PLoS One 2014;9:e87343. [CrossRef]

21. Sargın OruçA, Seçkin B, Özcan N, Özyer S, Uzunlar Ö, Danışman $\mathrm{N}$. Role of postprandial bile acids in prediction of perinatal outcome in intrahepatic cholestasis of pregnancy. J Obstet
Gynaecol Res 2014;40:1883-9. [CrossRef]

22. Madazli R, Yuksel MA, Oncul M, Tuten A, Guralp O, Aydin B. Pregnancy outcomes and prognostic factors in patients with intrahepatic cholestasis of pregnancy. J Obstet Gynaecol 2015;35:358-61. [CrossRef]

23. Berg B, Helm G, Petersohn L, Tryding N. Cholestasis of pregnancy. Clinical and laboratory studies. Acta Obstet Gynecol Scand 1986;65:107-13. [CrossRef]

24. Jin J, Pan SL, Huang LP, Yu YH, Zhong M, Zhang GW. Risk factors for adverse fetal outcomes among women with earlyversus late-onset intrahepatic cholestasis of pregnancy. Int J Gynaecol Obstet 2015;128:236-40. [CrossRef]

25. Yule CS, Holcomb DS, Kraus AC, Brown CEL, Mclntire DD, Nelson DB. Cholestasis: A prospective study of perinatal outcomes and time to symptom improvement. Am J Perinatol 2021;38:414-20. [CrossRef]

26. Behboudi-Gandevani S, Amiri M, Bidhendi Yarandi R, Ramezani Tehrani F. The impact of diagnostic criteria for gestational diabetes on its prevalence: A systematic review and meta-analysis. Diabetol Metab Syndr 2019;11:11. [CrossRef]

27. Ives CW, Sinkey R, Rajapreyar I, Tita ATN, Oparil S. Preeclampsia-pathophysiology and clinical presentations: JACC State-ofthe-Art review. J Am Coll Cardiol 2020;76:1690-702. [CrossRef]

28. Di Mascio D, Quist-Nelson J, Riegel M, George B, Saccone G, Brun $R$, et al. Perinatal death by bile acid levels in intrahepatic cholestasis of pregnancy: A systematic review. J Matern Fetal Neonatal Med 2021;34:3614-22. [CrossRef] 